\title{
(1)
}

Original Articles

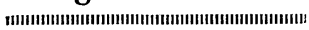

\section{Comparison of the Antimicrobial Activity of Various Agricultural Chemicals against Phytopathogenic Bacteria and Fungi Recently Isolated from Diseased Plants}

\author{
Hisashi SakuraI, Shoko Fujita and Hisashi NaIto \\ Agricultural Chemicals Inspection Station, Ministry of Agriculture and Forestry, \\ Kodaiva Tokyo 187, Japan
}

(Received September 13, 1976)

\begin{abstract}
The minimal inhibitory concentrations (MIC) values of various antibiotics and agricultural chemicals for isolates of Evwinia carotovora, Pseudomonas lachrymans, Alternaria mali, Alternaria kikuchiana, Botrytis sp. and Sclerotinia sp. collected in various localities of Japan were examined to determine the cross-resistance to various chemicals. To minimize the effects of various conditions, data on MIC values for isolates tested were pooled for 2 or 3 years, and the correlogram of the MIC values between an antimicrobial agent and the other agricultural chemicals were plotted in a single figure. The cross-resistance to an antimicrobial agent of isolates of the bacteria and fungi coincident with the resistance to the other agricultural chemicals was determined, and the relationships between MIC values for the isolates of the gray mold fungus (Botrytis sp.) and the control of the gray mold disease by benomyl and thiophanate methyl were found to be correlated each other.
\end{abstract}

The multiple resistance of organisms to various chemicals has been increasing over a long period of time, and it causes serious problems in the field of antibacterial drugs, veterinary drugs and insecticides. Recently, it was reported that some phytopathogenic bacteria and fungi resistant to antibiotics and synthetic fungicides were isolated from diseased plants in the fields and such resistant strains were rapidly distributed increasingly every year. ${ }^{1,2)}$

The resistance to benomyl of some phytopathogenic fungi was reported to coincide with that to the other benzimidazole derivatives and also to thiophanate methyl. ${ }^{3-6)}$ Uesugi et al. ${ }^{7}$ reported that the resistance to S-benzyl $O, O$ diethyl phosphorothioate of Pyricularia oryzae coincided with the resistance to $S$-benzyl $O, O$ diisopropyl phosphorothioate and $O$-ethyl $S, S$ diphenyl phosphorodithioate, except phosphoro- amide acid ester, from studies on laboratory. We also reported that kasugamycin-resistant strains of $P$. oryzae had cross-resistance to blasticidin $\mathrm{S}$ and polyoxin D. ${ }^{8,9)}$

Minimal inhibitory concentration (MIC) values of chemicals for the phytopathogenic bacteria and fungi obtained from diseased plants from 1971 to 1976 were studied. A method for establishing the appropriate MIC values was described in the previous paper, ${ }^{10}$ ) and such values were used for grouping the isolates into sensitive and resistant strains. To minimize the effects of variable conditions, data on MIC values of chemicals for the isolates of the bacteria and fungi studied were pooled over 2 years, and the correlogram of the MIC values between an antimicrobial agent and other agricultural chemicals were plotted in a single figure, and the relationships between the MIC values for the isolates of the gray 
mold fungus (Botrytis sp.) and the control of gray mold disease of the plants were investigated in the present study.

\section{MATERIALS AND METHODS}

\section{Strains of Phytopathogenic Bacteria and Fungi}

The phytopathogenic bacteria and fungi used for this study were obtained from diseased plants in various localities of Japan. They were 113 isolates of Erwinia carotovora, 93 of Pseudomonas lachrymans, 131 of Alternaria mali, 88 of Alternaria kikuchiana, 203 or 115 of Botrytis sp. and 82 of Sclerotinia sp. (Figs. 1 to 10$)$.

\section{Antibiotics and Fungicides}

Antibiotics and fungicides used in this study were: Blsaticidin $\mathrm{S}(\mathrm{BcS})$, kasugamycin $(\mathrm{KsM})$, polyoxin $\mathrm{B}(\mathrm{PoB})$, streptomycin $(\mathrm{SM})$, tetrachloroisophthalonitrile (chlorothalonil), methyl 2-bemzimidazolecarbamate (carbendazim), methyl 1-(butylcarbamoyl)-2-benzimidazolecarbamate(benomyl), dimethyl 4,4-o-phenylene bis(3-thioallophanate)(thiophanate methyl), $N$-(3,5-dichlorophenyl)-1,2-dimethylcyclopropanedicarboximide (S-7131) and $\mathrm{CuSO}_{4}$.

\section{SENSITIVITY TEST (MIC)}

MIC values of antibiotics and fungicides for the phytopathogenic bacteria and fungi were determined by the streak method for the bacteria, and the mycelial fragment method for the fungi using agar media with these chemicals in two-fold serial dilutions. For the bacteria, and fungi, King $\mathrm{B}$ medium, ${ }^{11)}$ and the polyoxin $\mathrm{B}$-potency-test medium ${ }^{12}$ ) were used, respectively. Data were obtained after 24 hours incubation at $28^{\circ} \mathrm{C}$ for the bacteria, and 48 hours at $26^{\circ} \mathrm{C}$ for the fungi.

\section{CONTROL OF PLANT DISEASE}

To examine the control of Botrytis sp. by benomyl or thiophanate methyl, detached leaves of Nijisseiki pear and of kidney bean, and sliced fruits of cucumber were used. Inocula were prepared by cutting 4 days-old mycelial mats of Botrytis sp. together with agar. The leaves and fruits were dipped in benomyl or thiophanate methyl solution for one hour before inoculation. Inoculation experiments were conducted by placing inocula on the detached leaves of Nijisseiki pear and kidney bean, or sliced fruits of cucumber, and incubating in the moist chamber at $25^{\circ} \mathrm{C}$. Data on the size of local lesions were obtained by daily observation for 3 days after inoculation.

\section{RESULTS AND DISCUSSION}

The correlogram of MIC values between an antimicrobial agent and the other agricultural chemicals for isolates of $E$. carotovora, $P$. lachrymans, A. mali, A. kikuchiana, Botrytis sp. and Sclerotinia sp. isolated from diseased plants in various localities of Japan was examined to clarify the cross-resistance in these isolates.

Therefore, the correlogam of the MIC values between an antimicrobial agent and the other agricultural chemicals were shown by pooling the data on the MIC values for the isolates of phytopathogenic bacteria and fungi for 2 or 3 years.

\section{(1) Erwinia carotovora}

As the MIC value of SM for grouping of isolates of $E$. carotovora into sensitive and resistant groups, the grouping value showed $50 \mu \mathrm{g} / \mathrm{ml}$ in the previous paper. ${ }^{10)}$ As shown in Fig. 1, the results demonstrate that SM-resist-

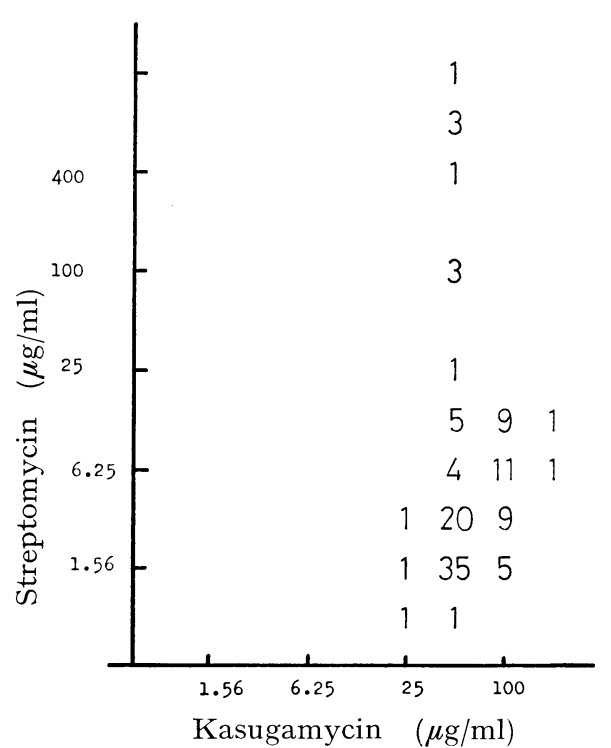

Fig. 1 Correlogram of MIC values between streptomycin and kasugamycin of Erwinia carotovora. (113 isolates) 


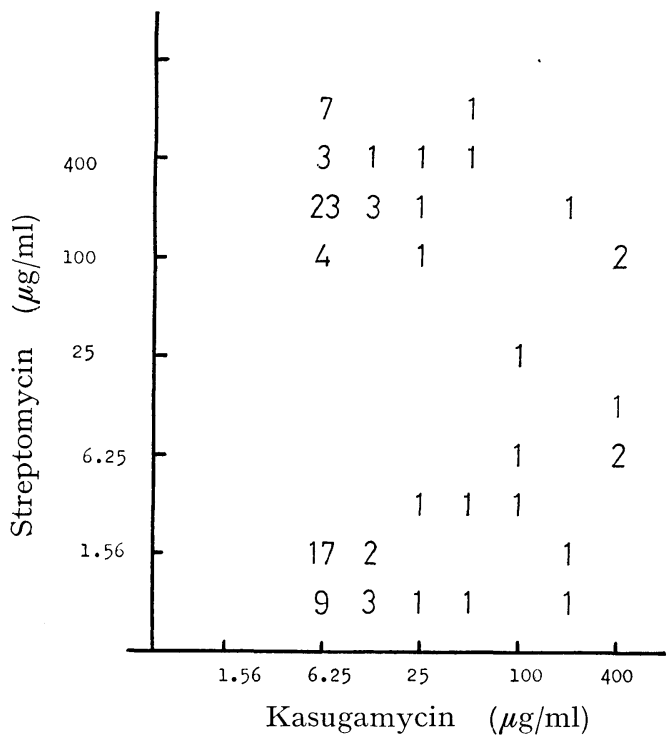

Fig. 2 Correlogram of MIC values between streptomycin and kasugamycin of Pseudomonas lachrymans (93 isolates).

ant strains of $E$. carotovora were insensitive to $\mathrm{KsM}$.

(2) Pseudomonas lachrymans

In P. lachrymans, the grouping value for SM showed $50 \mu \mathrm{g} / \mathrm{ml}$ in the previous paper. ${ }^{10)}$ As shown in Fig. 2, the results demonstrate that SM-resistant strains of $P$. lachrymans were sensitive to KsM except two isolates.

(3) Alternaria mali

In $A$. mali, the MIC value of antibiotics for grouping of isolates into sensitive and resistant groups, the grouping value for $\mathrm{PoB}$ showed $50 \mu \mathrm{g} / \mathrm{ml}$. For MIC of $\mathrm{BcS}$, the grouping value showed $100 \mu \mathrm{g} / \mathrm{ml}$ in the previous paper. ${ }^{10)}$ As shown in Fig. 3, the results demonstrate that PoB-resistant strains of $A$. mali were sensitive to $\mathrm{BcS}$.

\section{(4) Alternaria kikuchiana}

The grouping value for $\mathrm{PoB}$ and $\mathrm{BcS}$ determined by pooling the value in isolates of A. kikuchiana showed $100 \mu \mathrm{g} / \mathrm{ml}$ and $100 \mu \mathrm{g} / \mathrm{ml}$ respectively, in the previous paper. ${ }^{10)}$ As shown in Fig. 4, the results demonstrate that PoBresistant strains of $A$. kikuchiana were sensitive to $\mathrm{BcS}$.

(5) Botrytis sp.

In Botrytis sp., the determination of the

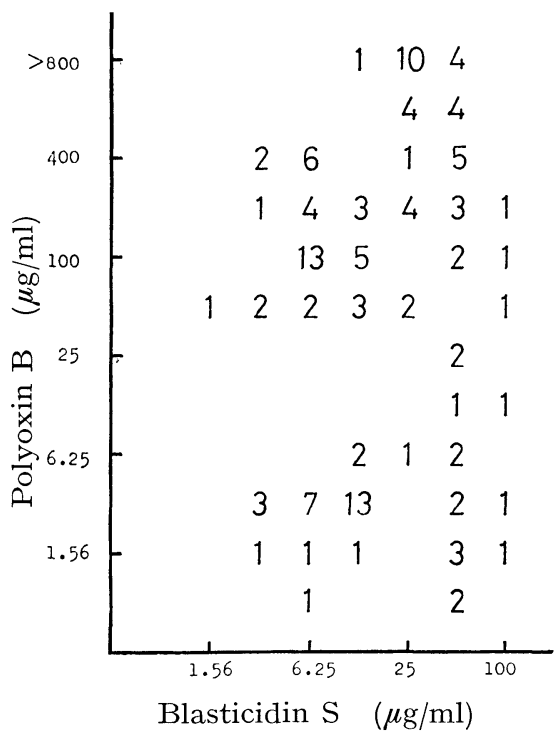

Fig. 3 Correlogram of MIC values between polyoxin $\mathrm{B}$ and blasticidin $\mathrm{S}$ of Alternaria mali (131 isolates).

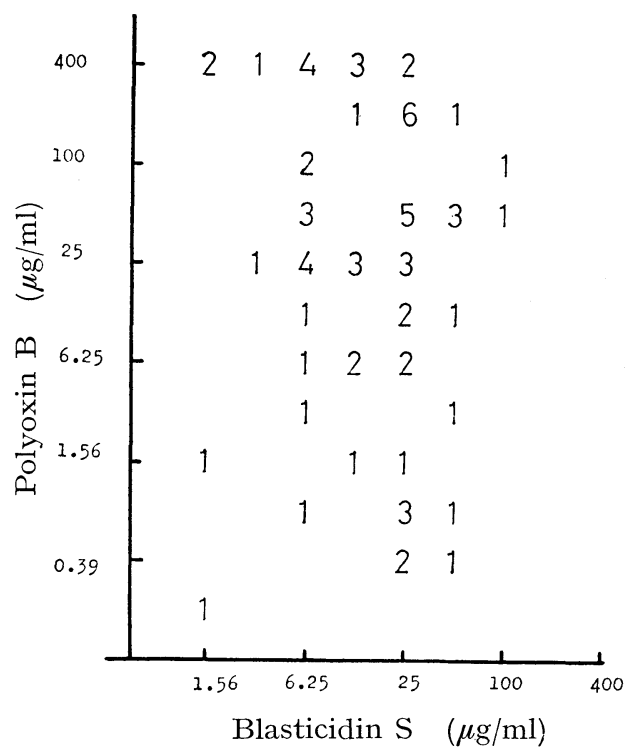

Fig. 4 Correlogram of MIC values between polyoxin $\mathrm{B}$ and blasticidin $\mathrm{S}$ of Alternaria kikuchiana (88 isolates).

grouping value for carbendazim showed 0.78 $\mu \mathrm{g} / \mathrm{ml}$ or $1.56 \mu \mathrm{g} / \mathrm{ml}$ and for chlorothalonil showed $25 \mu \mathrm{g} / \mathrm{ml}$ in the previous paper. ${ }^{10)}$ As shown in Figs. 5, 6, 7 and 8, carbendazimresistant strains of Botrytis sp. were sensitive 


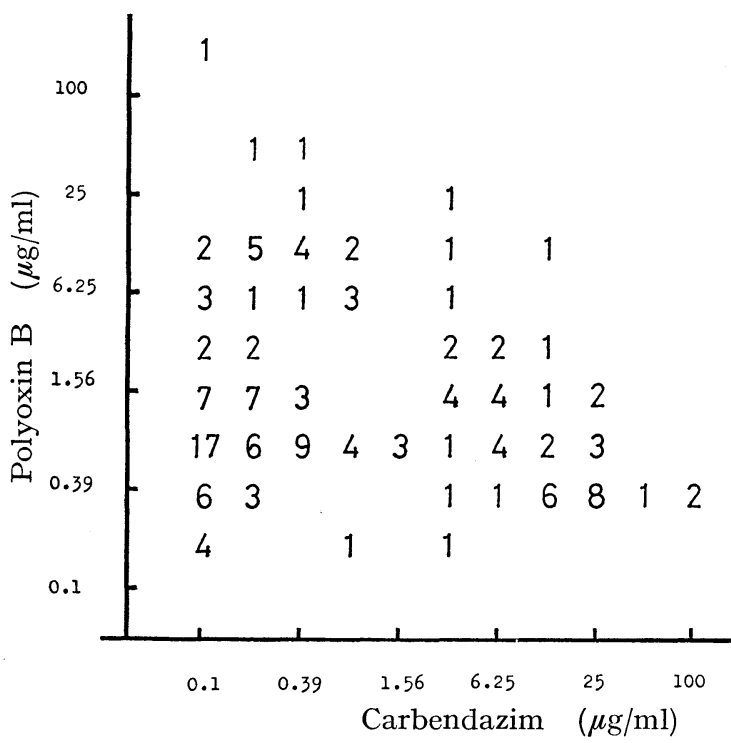

Fig. 5 Correlogram of MIC values between polyoxin B and carbendazim of Botrytis sp. (203 isolates).

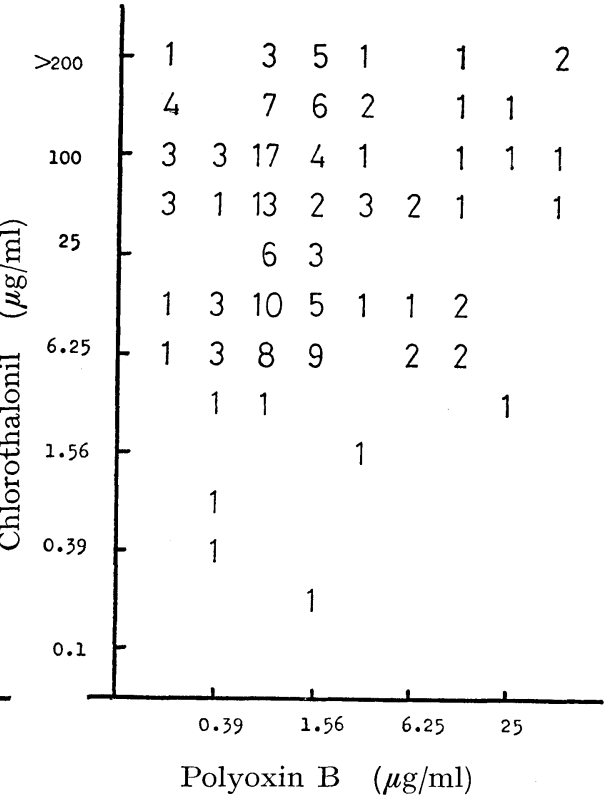

Fig. 6 Correlogram of MIC values between polyoxin $\mathrm{B}$ and chlorothalonil of Botrytis sp. (155 isolates).

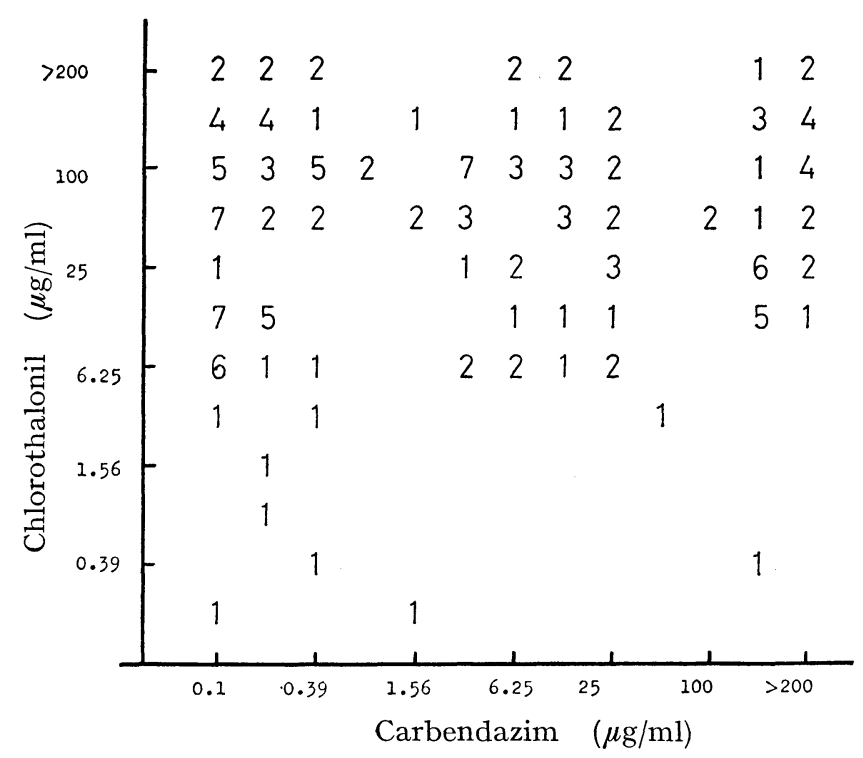

Fig. 7 Correlogram of MIC values between carbendazim and chlorothalonil of Botrytis sp. (155 isolates).

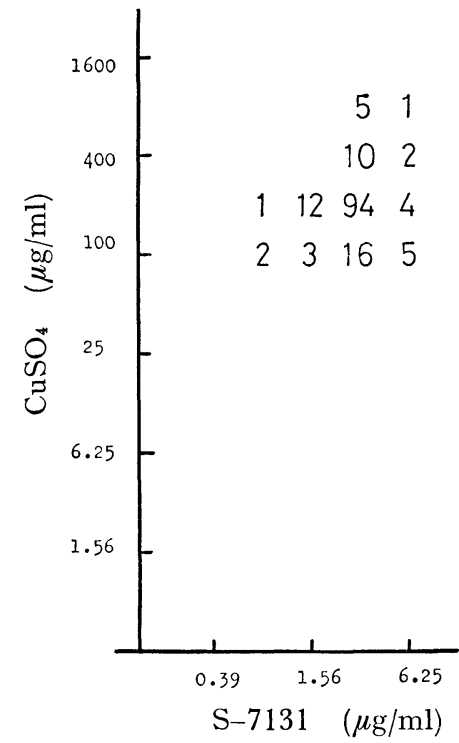

Fig. 8 Correlogram of MIC values between S-7131 and $\mathrm{CuSO}_{4}$ of Botrytis sp. (155 isolates). to $\mathrm{PoB}$ or $\mathrm{CuSO}_{4}$. However, some carbendazim-resistant strains of Botrytis sp. showed double-resistance to chlorothalonil (Fig. 7). All isolates were sensitive to $\mathrm{S}-7131$ and
$\mathrm{CuSO}_{4}$.

(6) Sclerotinia sp.

As described in the previous paper, ${ }^{10)}$ all isolates of Sclerotinia sp. tested were sensitive 


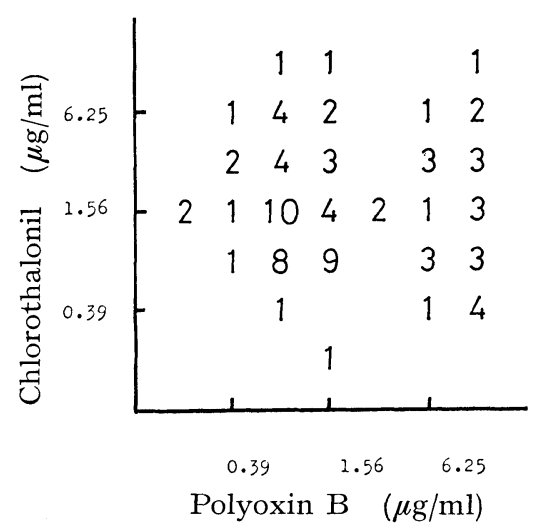

Fig. 9 Correlogram of MIC values between polyoxin B and chlorothalonil of Sclerotinia sp. (82 isolates).

to carbendazim, chlorothalonil, $\mathrm{PoB}$ and $\mathrm{CuSO}_{4}$ (Figs. 9 and 10).

The relations between MIC of carbendazim for the isolates of Botrytis sp. and the control of the gray mold disease by both benomyl and thiophanate methyl in vivo were correlated each other. Carbendazim-resistant strains of Botrytis sp. had cross-resistance to benomy and thiophanate methyl on the control of gray mold disease (Tables 1 and 2). These results were similar to those of both in vitro and in vivo

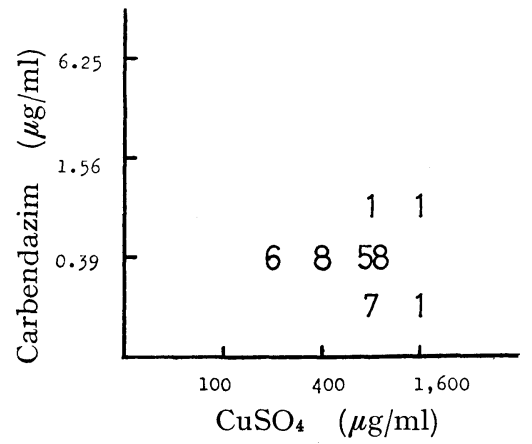

Fig. 10 Correlogram of MIC values between carbendazim and $\mathrm{CuSO}_{4}$ of Sclerotinia sp. (82 isolates).

activity of $\mathrm{KsM}$ and $\mathrm{BcS}$ against Pyricularia oryzae. ${ }^{8-10)}$

The in vitro activity of benomyl and some chemically related compounds against the fungi tested clearly demonstrates the resistance to the other benzimidazole derivatives and also to thiophanate methyl, and cross-resistance to benomyl and thiophanate methyl. These results may be explained by the fact that thiophanate methyl in tap water, plant tissues and soil gives rise to carbendazim, and the same compound is formed rapidly in aqueous solution of benomyl. ${ }^{12-18)}$

Table 1 The relation between MIC of carbendazim in isolates of Botrytis sp. and preventive effect of the gray mold disease by benomyl on the plant.

\begin{tabular}{|c|c|c|c|c|c|c|c|c|c|}
\hline \multirow{3}{*}{$\begin{array}{l}\text { Class of } \\
\text { MIC of } \\
\text { carben- } \\
\text { dazim }\end{array}$} & \multicolumn{3}{|c|}{ Cucumber (fruit) } & \multicolumn{3}{|c|}{ Nijisseiki pear (leaf) } & \multicolumn{3}{|c|}{ Kidney bean (leaf) } \\
\hline & \multirow{2}{*}{$\begin{array}{l}\text { No. of } \\
\text { isolates }\end{array}$} & \multicolumn{2}{|c|}{$\begin{array}{l}\text { Diameters of } \\
\text { lesions tested* }\end{array}$} & \multirow{2}{*}{$\begin{array}{l}\text { No. of } \\
\text { isolates }\end{array}$} & \multicolumn{2}{|c|}{$\begin{array}{c}\text { Diameters of } \\
\text { lesions tested }\end{array}$} & \multirow{2}{*}{$\begin{array}{l}\text { No. of } \\
\text { isolates }\end{array}$} & \multirow{2}{*}{\multicolumn{2}{|c|}{$\begin{array}{l}\text { Diameters of } \\
\text { lesions tested* }\end{array}$}} \\
\hline & & Sensitive & Resistant & & Sensitive & Resistant & & & \\
\hline 0.1 & 5 & 5 & 0 & 7 & 7 & 0 & 5 & 5 & 0 \\
\hline 0.2 & 4 & 4 & 0 & 7 & 7 & 0 & 5 & 5 & 0 \\
\hline 0.39 & 5 & 5 & 0 & 7 & 7 & 0 & 5 & 5 & 0 \\
\hline 0.78 & 2 & 2 & 0 & 2 & 2 & 0 & 2 & 2 & 0 \\
\hline 1.56 & 3 & 3 & 0 & 3 & 3 & 0 & 3 & 3 & 0 \\
\hline 3.12 & 5 & 5 & 0 & 6 & 5 & 1 & 5 & 4 & 1 \\
\hline 6.25 & 5 & 4 & 1 & 6 & 4 & 2 & 4 & 2 & 2 \\
\hline 12.5 & 5 & 2 & 3 & 6 & 4 & 2 & 4 & 2 & 2 \\
\hline 25 & 5 & 2 & 3 & 7 & 3 & 4 & 5 & 2 & 3 \\
\hline 50 & 1 & 0 & 1 & 1 & 0 & 1 & 1 & 0 & 1 \\
\hline 100 & 2 & 0 & 2 & 2 & 0 & 2 & 2 & 0 & 2 \\
\hline 200 & 4 & 0 & 4 & 6 & 0 & 6 & 5 & 0 & 5 \\
\hline$>200$ & 4 & 0 & 4 & 5 & 0 & 5 & 4 & 0 & 4 \\
\hline
\end{tabular}

* Percent decrease in diameter of local lesion per inoculation by application of a $250 \mu \mathrm{g} / \mathrm{ml}$ solution of benomyl. 
Table 2 The relation between MIC of carbedazim in isolates of Botrytis sp. and preventive effect of the gray mold disease by thiophanate methyl on the leaf of kidney bean.

\begin{tabular}{cccc}
\hline \multirow{2}{*}{$\begin{array}{c}\text { Class of } \\
\text { MIC of } \\
\text { carben- } \\
\text { dazim }\end{array}$} & \begin{tabular}{c} 
Ko. of \\
\cline { 2 - 4 } isolates
\end{tabular} & $\begin{array}{c}\text { Kidney bean (leaf) } \\
\text { Diameters of } \\
\text { lesions tested }\end{array}$ \\
\cline { 3 - 4 } & & Sensitive & Resistant \\
\hline 0.2 & 3 & 3 & 0 \\
0.39 & 3 & 3 & 0 \\
0.78 & 2 & 2 & 0 \\
1.56 & 3 & 3 & 0 \\
3.12 & 3 & 3 & 0 \\
6.25 & 3 & 2 & 1 \\
12.5 & 3 & 1 & 2 \\
25 & 3 & 1 & 2 \\
50 & 1 & 0 & 1 \\
100 & 2 & 0 & 2 \\
200 & 3 & 0 & 3 \\
200 & 3 & 0 & 3 \\
\hline
\end{tabular}

* Percent decrease in diameter of local lesion per inoculation by application of a $460 \mu \mathrm{g} / \mathrm{ml}$ solution of thiophanate methyl.

A detailed comparison of the sensitivity and accuracy of both the MIC test and the control effect of the agricultural chemicals on the plant disease produced with many isolates of phytopathogenic bacteria and fungi has been made. Furthermore the correlogram of MIC values shown in this study might not be applicable at the concentrations of agricultural chemicals used in the fields. However, we reported that the relationships between MIC value in isolates and control of disease on the plant in which $E$. carotovora to SM, A. kikuchiana to $\mathrm{PoB}$ and $P$. oryzae to $\mathrm{KsM}$ and $\mathrm{BcS}$ were correlated to each other in the previous paper. ${ }^{10}$ When used together with the knowledge of a method of application and of the pharmacokinetics of agricultural chemicals, the correlogram of MIC values between an antimicrobial agent and the other agricultural chemicals contribute information that would be useful for application of agricultural chemicals in the field.

\section{ACKNOWLEDGEMENTS}

The authors are indebted to Prof. S. Mitsuhashi, department of microbiology, school of medicine, Gunma University, Japan, for his interest and encouragement, and wish to thank plant disease laboratories of some organization, Japan, for providing some isolates of phytopathogenic bacteria and fungi.

\section{要 約}

最近全国各地の罹病植物から分離された数種植物病原 菌株の薬剂感受性值について，寒天平板希䣋法による MIC で測定し，各菌株の示す数種薬剂間の感受性值を 比較した。 その結果，野菜類の軟腐病菌およびキュウリ 斑点細菌病菌の示すストレプトマイシンおよびカスガマ イシン感受性值の間に相関はなかったが，ストレプトマ イシン耐性キュウリ斑点細菌病菌のなかで，2 菌株がカ スガマイシンに耐性を示した。リンゴ斑点落葉病菌およ びナシ黑斑病菌の示すポリオキシン $\mathrm{B}$ およびブラスト サイジン S 感受性值の間に相関は認められなかった。灰 色かび病菌に括いて, carbendazim, chlorothalonil, ポオリキシン B， S-7131 および硫酸銅に対する感受性 值は各薬剂間に相関はなかった。しかし carbendazim および chlorothalonil に耐性を示す二剂耐性菌が分布 していることが認められた。菌核病菌では供試薬戍に耐 性を示す菌株は認められなかった。 各菌株の示す MIC 值と植物体上に技ける防除効果を調べた結果，灰色かび 病菌において carbendazim の MIC 值とべノミルお よびチオフォネートメチルの灰色かび病防除効果は相関 することが認められたが，in vitro で中等度耐性菌と推 定される菌株群のなかで，植物体上に打ける防除効果が 菌株によって感受性または耐性を示すという現象も観察 された。

\section{REFERENCES}

1) W. Iida: Shokubutsu bōeki 29, 163 (1975)

2) Y. Uesugi: ibid. 29, 167 (1975)

3) G. J. Bollen \& G. Scholten: Neth. J. Path. 77, 83 (1971)

4) G. J. Bollen: ibid. 77, 187 (1975)

5) J. B. Schooley \& B. H. MacNeil: Phytopath. 61, 816 (1971)

6) J. M. Vargas: ibid. 63, 1366 (1973)

7) Y. Uesugi, M. Katagiri \& K. Fukunaga: Bull. Nat. Inst. Agric. Sci. C 23, 93 (1969)

8) H. Sakurai, H. Naito \& K. Yoshida: Bull. Agric. Chem. Inspect. Stn. No. 15, 82 (1975)

9) H. Sakurai \& H. Naito: J. Antibiotics 29, 1341 (1976)

10) H. Sakurai, H. Naito \& S. Fujita: $J$. Antibiotics 29, 1230 (1976)

11) H. Naito, H. Sakurai \& K. Yoshida: Bull. Agric. Chem. Inspect. Stn. No. 15, 120 (1975) 
12) H. Sakurai \& T. Shimada: ibid. No. 14, 54 (1974)

13) J. W. Vonk \& A. K. Sijpesteijn: Pest. Sci. 160 (1971)

14) J. J. Kirkland: J. Agric. Food Chem. 21, 171 (1973)

15) J. J. Kirkland, F. H. Richard \& L. P.
Harlan: ibid. 21, 368 (1973)

16) H. A. Selling, J. W. Vonk \& A. K. Sijpesteijn: Chem. Inds. Lond. 1970, 1625 (1970)

17) H. D. Sisler: Abstr. 2nd int. Congr. Pesti. Chem. (Tel Aviv), p. 931971

18) G. P. Clemons \& H. D. Sisler: Phytopathology 59, 705 (1969) 